\title{
Poskus orisa izzivov v upravljanju Mitskega parka v Rodiku
}

\author{
Neža Čebron Lipovec \\ Univerza na Primorskem \\ neza.cl@fhs.upr.si
}

\section{Uvod}

Novonastali Čezmejni mitski park predstavlja noviteto v sklopu oblik upravljanja kulturne dediščine. Kot pove ime, park temelji na vsebinah, ki izhajajo iz nesnovne dediščine mitskega izročila, a vsebuje tudi številne druge snovne elemente. To so arheološka najdišča, stavbna dediščina, naravne vrednote in umetniška dela.

Bogat nabor različnih prepoznanih kulturnih in naravnih vrednot, ki sooblikujejo Mitski park Rodik, je upravljavce (Občino Hrpelje-Kozina in posebej Turistično združenje Rodik) in strokovne svetovalce vodil k odločitvi, da oblikujejo enoten načrt upravljanja za celoten park, ne zgolj za tista območja, ki jih predvideva Zakon o varstvu kulturne dediščine ( $\mathrm{ZVKD}-1$ ) (2008). Naloga je še v pripravah, v tem prispevku pa želimo osvetliti nekaj vsebinskih vprašanj, ki se skozi snovanje parka in načrtovanje njegovega upravljanja izkazujejo kot izziv. Osrednje vprašanje zadeva značilnosti mitske krajine ter njenih sestavnih elementov. Problem razčlenjujemo $\mathrm{z}$ analizo posameznih varovanih elementov kot tudi elementov, ki tega statusa še nimajo, a so integralni del upravljanja, ter orisujemo nekatere ključne upravljavske naloge. V poglavju o čezmejnosti primerjamo upravljavske izzive v Rodiku in v »bratskem " parku v Mošćenički Dragi. V sklepu poskušamo orisati okvirne usmeritve, kako se s temi izzivi spopasti. Rodiški Mitski park obravnavamo kot študijo primera za upravljanje mitske krajine, ki lahko služi kot referenca za morebitne sorodne primere.

\section{Upravljanje kulturne dediščine}

Upravljanje je lahko definirano zelo tehnicistično; v slovenskem Zakonu o varstvu kulturne dediščine (ZVK D-1) (2008, 3. točka 37. člena) je definirano kot "izvajanje nalog, ki so potrebne za izpolnitev namena, zaradi katerega je bila stvar razglašena za spomenik, in obsega predvsem vodenje in organiziranje vzdrževanja, uporabe, dostopnosti, predstavitve javnost in 
spremljanje stanja."V sodobnih slovenskih interpretacijah zakonodajnih podlag pa je izpostavljen en vidik - to je pomen vključevanja lokalne skupnosti (Plestenjak in Stokin 2016, 13; Pirkovič 2018, 75-76). V tem se slovenski okvir upravljanja navezuje na sodobni mednarodni kontekst, ki trajnostno upravljanje primarno opredeljuje v odnosu do nosilcev dediščine. V tem sta ohranjanje in upravljanje opredeljena ne zgolj kot "upravljanje sprememb (Teutonico in Matero 2003), temveč kot »upravljanje kreativne kontinuitete in družbeno organizirana dediščinska praksa" (Chitty 2017, 10). V mednarodnih strokovnih krogih je upravljanje dediščine že dobro razvito in uveljavljeno, predvsem v Avstraliji in Angliji, od koder izhajajo glavni teoretski teksti (Clark 2014; Kerr 2013; Heritage Lottery Fund 2001), kot tudi v Kanadi. Sodobno področje upravljanja dediščine tako ponuja bogat nabor navodil in vzorcev, kako pripraviti načrte upravljanja in ga nato izvajati (Plestenjak, Stokin in Zanier 2014; Wijesurijya, Thompson in Young 2013; Palumbo 2000; Feilden in Jokilehto 1998).

\section{Načrti upravljanja}

Konceptualni okvir upravljanja dediščine temelji na pojmih identify (prepoznaj), protect (zaščiti), conserve (ohrani) in present (predstavi) in je v slovenskem kontekstu preoblikovan $\mathrm{v}$ temeljne sklope, ki sestavljajo upravljanje in njegovo glavno orodje - načrt upravljanja (NU) (Plestenjak Stokin in Zanier 2014). V slovenskem kontekstu je upravljanje dediščine še izrazito v povojih, saj je N U z zakonom iz leta 2008 (zV K D-1) uradno zahtevan zgolj za spomeniška območja, ki imajo upravljavca. Področje upravljanja pa se medtem intenzivno razvija na področju varstva narave, kjer je $\mathrm{NU}$ prav tako zahtevan za zavarovana območja, ki imajo $\mathrm{NU}$ predviden $\mathrm{v}$ razglasitvenem aktu (Zakon o ohranjanju narave ( $\mathrm{ZON}$-U P B 2) 2004).

Izhodišče vsakršnega upravljanja je temeljito poznavanje dediščine (razvoj, stanje ohranjenosti in ogroženosti) in njeno celovito vrednotenje; na osnovi tega se oblikujejo vizija ohranjanja ter strateški in izvedbeni cilji. $\mathrm{Na}$ osnovi slednjih pa se strukturirajo ukrepi, torej konkretne upravljavske naloge, po štirih temeljnih sklopih: v načrtu upravljanja znanja (planiranje raziskav in hramba informacij), načrtu varstva in ohranjanja (varstveni postopki, torej konservatorski posegi, monitoring itd.), načrtu valorizacije (prezentacija, interpretacija, popularizacija) in pa komunikacijskem načrtu. Vse naloge morajo biti ustrezno časovno opredeljene (po prioritetah: kratko-, srednje- in dolgoročno) in finančno ovrednotene, vključno $z$ dostopnimi ali načrtovanimi finančnimi viri. Ključno orodje monitoringa in ocenjevanja uspešnosti upravljanja pa so kazalniki, torej merljivi rezul- 
tati, ki jih želimo doseči. Vsak načrt upravljanja mora imeti tudi rok trajanja (običajno največ pet let, pogosto manj). Sledi ponovna valorizacija, saj novo upravljanje lahko privede do sprememb na dediščini oz. se prepozna nove potrebe pri varovanju. Eno bistvenih izhodišč je dejstvo, da so načrti upravljanja zgolj orodja za izvajanje nalog in jih je potrebno redno prilagajati ter osveževati (Kerr 2013, 26; Wijesuriya, Thompson in Young 2013, 123; Plestenjak, Stokin in Zanier 2014, 167).

\section{Lokalna skupnost}

Upravljanje temelji na razumevanju in vrednotenju (angl. values-led approach; Wijesuriya, Thompson in Young 2013), torej je vsakršen konkretni poseg odvisen od prehodnega prepoznavanja pomena in ocene ranljivosti ter ogroženosti. Načela upravljanja, in torej načrti upravljanja kot orodje, so zasnovani dokaj univerzalno in jih je moč prilagajati različnim zvrstem dediščine.

V evropskem kontekstu se NU uporabljajo skoraj izključno za snovno dediščino. Nesnovna dediščina $v$ teh dokumentih nima definirane posebne pozicije oziroma se jo umešča po potrebi, $\mathrm{v}$ okviru razumevanja dediščine (Wijesuriya, Thompson in Young 2013, 61). V evropskem kontekstu je v splošnih navodilih zgolj omenjena (Heritage Lottery Fund 2001, 5), ta odnos odseva značilno evropsko materialistično naravnanost $\mathrm{v}$ ohranjanju in upravljanju dediščine (Willems 2010). V drugih kulturnih kontekstih, posebej kjer so prisotne staroselske skupnosti (vzorčni primer je Avstralija), je odnos do upravljanja veliko celovitejši in stremi k enakovrednemu in skupnemu vrednotenju tako snovnih kot nesnovnih elementov. Srž tega odnosa pooseblja IC OMO S-ova burska listina (oblikovana že konec 1970ih let, a sprejeta leta 1999), ki poudarja »kulturni pomen« dediščine (angl. cultural significance) kot temelj vsakršnega upravljanja in predstavljanja dediščine. A tudi v tem primeru je bistvenega pomena, kdo to dediščino vrednoti in kateri diskurz se ob tem vzpostavlja. Kot v svojem temeljnem delu opozarja Laurajane Smith (2006), v dediščini prepogosto prevladuje "avtorizirani dediščinski diskurz" (angl. authorised heritage discourse, $A H D$ ), ki temelji izključno na strokovni presoji o pomenu dediščine, ki perpetuira enoglasno razlago pomenov dediščine. Da bi bilo vrednotenje, in torej ohranjanje, celovito, pa mora to nujno izhajati (tudi) iz "podrejenega" (angl. subaltern discourse), torej perspektive dotične lokalne skupnosti, tudi če se ne sklada s strokovnim vrednotenjem. Vsakršno upravljanje torej temelji na dveh bistvenih predpostavkah - ena je temeljito poznavanje dediščine, torej različnih vrednosti, ki jih dediščini pripisujejo tako stroka kot 
skupnost; druga pa je ustrezni upravljavski okvir, ki naj izhaja iz skupnostnega ovrednotenja te dediščine.

Pobuda za oblikovanje rodiškega Mitskega parka sicer raste iz znanstveno-raziskovalnih odkritij etnološke in arheološke stroke, primarno iz raziskav dr. Katje Hrobat Virloget, a so rezultati teh raziskav poželi izjemno podporo na lokalni ravni. Slednjo odseva sama prijava projekta Interreg "Mitski park«, katerega vodilni partner je Občina Hrpelje-Kozina, ter njegova izjemno uspešna izvedba. Poseben vidik uspešnosti je prav vzpostavitev sodelovanja med znanstveno stroko, lokalno oblastjo in lokalno skupnostjo, ki je aktivno sodelovala v nastajanju parku. Lokalna skupnost je bila osrednjega pomena že znotraj same raziskave, saj je ta temeljila na zbiranju ustnega izročila o prostoru. $V$ Rodiku bo tako upravljanje parka poverjeno režijskemu obratu Občine Hrpelje-Kozina, ki ga bo izvajal v sodelovanju s Turističnim društvom Rodik. Naj tu opozorimo že na prvi izziv: ustroj organizacijske strukture upravljavskega telesa je bistvenega pomena (Plestenjak in Stokin 2016), saj mora biti upravljanje ustrezno usklajevano in usmerjeno. $V$ ta namen se v primerih, ko gre za uradno razglašeno dediščino oz. lokalne ali državne spomenike, mora vključiti stroko, torej predstavnike Zavoda za varstvo kulturne dediščine, ki naj bi izvajali nadzor nad upravljavskimi dejavnostmi. V primeru Mitskega parka pa bi bilo smiselno oblikovanje svetovalnega organa, svojevrstnega "sveta zavoda«, ki usmerja delovanje upravljavskega telesa. $\mathrm{V}$ tem telesu morajo biti enakovredno vključeni tako predstavniki lokalnih oblasti in lokalne skupnosti kot predvsem stroke - kot bo razvidno v nadaljevanju.

\section{Elementi upravljanja v Mitskem parku Rodik}

Park obsega več hektarov poseljenega in naravnega območja, v katerem je umeščenih dvanajst točk itinerarija parka. Temelj parka je nesnovna dediščina, to je mitska krajina, ki pa jo sooblikuje snovno naravno in antropogeno okolje. Konkretni upravljavski izzivi v primeru rodiškega parka tako zadevajo več elementov upravljanja: na ravni same lokacije izpostavimo predvsem ohranjanje varovane kulturne dediščine (vpisane v Register kulturne dediščine Slovenije ${ }^{1}$ ) kot tudi umetniških elementov v parku, a predvsem ohranjanje in upravljanje nesnovne dediščine ter $\mathrm{v}$ zvezi s to pogojno tudi ohranjanje (kulturne) krajine. $Z$ vidika čezmejnosti pa se odpira vprašanje vzpostavitve enotnih kriterijev upravljanja z Mošćeničko Drago. V nadaljevanju analiziramo predvsem dva značilna elementa upravljanja: to

${ }^{1}$ Glej https://gisportal.gov.si. 
sta razumevanje dediščine in njenih vrednot ter ocena ranljivosti in ogroženosti.

\section{Registrirana dediščina in spomeniki}

Na obravnavanem območju se nahaja več enot dediščine, ki so varovane z Zakonom o varstvu kulturne dediščine (zVKD-1) in vpisane v Register kulturne dediščine. Vas Rodik je registrirana dediščina (evidenčna številka dediščine - EŠ D 16061), cerkev sv. Trojice v njem pa kot spomenik lokalnega pomena (E ŠD 3976). Več je lokacij arheološke dediščine:

- Arheološko najdišče Ajdovščina, ki ima edino status spomenika lokalnega pomena (E Š D 624) in obsega utrjeno naselbino (prazgodovinsko gradišče, središče Rundiktov, s kontinuiteto v pozno antiko) na osamelem hribu Ajdovščina ter zgodnjerimske grobove Na Sedlu in Pod Jezerom. Zaradi izjemnega pomena in ohranjenosti te lokacije je bila že oblikovana zamisel, v dogovoru med Občino Hrpelje-Kozina in Zavodom za varstvo kulturne dediščine, da bi najdišče dobilo status spomenika državnega pomena.

- Arheološko najdišče Tabor (E ŠD 7306), ki obsega ruševine verjetno srednjeveškega zidanega objekta z obzidjem.

- Arheološko območje Križen drev (E ŠD 17290), kjer se nahaja časovno neopredeljiva utrjena postojanka, ohranjena kot groblja na platoju $\mathrm{z}$ maltnim vezivom in obdelanimi kamni; v izročilu je to bila postaja ob stari poti iz Rodika na Artviže.

- Arheološko najdišče Debela griža (E ŠD 7278), kjer se nahaja prazgodovinska utrjena naselbina, postavljena v nižini sredi osmih kraških vrtač. Postavljena je v naravno obrambno lego, v celoti pa je ohranjen kamnit obrambni okop izjemnih dimenzij. Severno od naselbine je spodmol z rimskodobnimi sledovi poselitve.

- Ob zahodnem robu vasi Rodik se nahaja še arheološko najdišče Krivice s statusom registrirane dediščine (E Š D 17304), kjer so bile odkrite najdbe, ki kažejo na obstoj grobišča iz obdobja antike ali zgodnjega srednjega veka, vendar najdišče ne sega na samo območje mitskega parka oziroma ne tvori točke na poteh parka.

Izmed teh enot je zgolj arheološko najdišče Ajdovščina, s statusom spomenika lokalnega pomena, tisto, ki kot spomeniško območje po zakonu potrebuje načrt upravljanja; slednji bo v primeru Mitskega parka integriran v upravljanje celotnega območja. Natančne in za najdišče specifične 
usmeritve za upravljanje dotičnega spomenika so v domeni odgovornih konservatorjev na Zavodu za varstvo kulturne dediščine. Status lokalnega spomenika ima tudi arheološko najdišče Debela Griža (Rodiška pečina, Remeščica), ki se ga pot mitskega parka ne dotika neposredno, čeprav je Remeščica vsebinsko del parka. Smiselno bi bilo v prihodnjih letih oblikovati smernice za upravljanje in interpretacijo tudi tega najdišča, ki bo nedvomno predmet bolj množičnih obiskov. V okviru parka bi bilo smiselno oblikovati tudi usmeritve za ohranjanje ostalih posameznih najdišč, ki imajo samo status dediščine.

\section{Ogroženost in ranljivost}

Arheološka dediščina je na splošno podvržena zelo raznolikim nevarnostim (Palumbo 200o), ki so lahko posledica onesnaževanja, prostorskega razvoja in pa pretirane turistične dejavnosti. Slednje se kaže primarno v eroziji snovnosti dediščine kot tudi v neustreznih rekonstrukcijah za potrebe prezentacije. Velik problem predstavljajo vandalizem, »detektoraštvo in plenjenje arheološke dediščine ter neavtorizirana izkopavanja. Med najpogostejše dejavnike propadanja arheološke dediščine pa štejemo neustrezen administrativno-upravljavski okvir, ki vodi v zanemarjanje in pomanjkanje vzdrževanja, predvsem preventivnega vzdrževanja (Cecchi in Gasparoli 2010).

Kot ključen vidik ranljivosti arheološke dediščine $\mathrm{v}$ rodiškem parku lahko izpostavimo prav pomen preventivnega vzdrževanja arheoloških struktur in njihove okolice ter nevarnost prevelikega pritiska turizma (uničevanje samih struktur, vandalizem). Pomemben ukrep za preprečevanje posledic pritiska obiska je vzpostavitev vsaj osnovnih interpretacijskih sredstev, kar prispeva $k$ obveščanju in ozaveščanju in stremi $k$ preprečevanju vandalizma (Palumbo 200o, 10). Slednje je doseženo prav z izvedbo interpretacije $v$ parku (tematska pot $z$ označevalci ter avdiovodnikom). Posebno pozornost bo potrebno posvetiti monitoriranju stanja ter rednemu vzdrževanju.

\section{Umetniška dela na območju mitskega parka}

$\mathrm{Na}$ tematski poti so ob vsaki točki umeščeni tudi kamniti prag, kamniti vertikalni označevalec oz. steber $z$ imenom točke, predvsem pa kamniti kip, ki ponazarja vsebino dotičnega izročila. Vse nove kamnite elemente sta zasnovala oblikovalka kamna Špela Šedivy ter akademski kipar Damjan Švara v sodelovanju s študenti Višje strokovne šole Sežana.

Posebnost je točka Babe, kjer je nekdaj stal veliki apnenčasti monolit, v 
katerem je prebivalstvo prepoznavalo podobo mitske figure Babe, a je danes uničen. Razstreljen je bil z dinamitom $\mathrm{v}$ času gradnje kraškega vodovoda po drugi svetovni vojni. Za potrebe interpretacije nesnovne dediščine mitske krajine je umetnik Marko Pogačnik sestavil novo podobo, ki se vsebinsko navezuje na izročilo o Babi. V duhu land arta in svojega umetniškega pristopa geopunktur je ustvaril novo postavitev iz ostankov monolita, in sicer v obliki mandorle, ki ponazarja maternico Zemlje. Postavitev je zasnovana kot zamejeni prostor, $\mathrm{v}$ katerega obiskovalec vstopa in se $\mathrm{v}$ njem osredotoča - na spoznano izročilo in na svojo percepcijo. Da je osredotočenost usmerjena, je prostor znotraj mandorle pokrit z gramozom. Umestitev umetniškega dela $\mathrm{v}$ sklop parka vidikom upravljanja dodaja še novo dimenzijo. Prisotnost inštalacije Marka Pogačnika kot tudi kamnitih kipov Špele Šedivy in Damjana Švare na posameznih točkah parka odpirajo posebno vprašanje vzdrževanja umetniškega dela na prostem.

\section{Ogroženost in ranljivost}

Za umetniška dela na prostem je pomembno jasno definirati vzdrževalni pristop in odnos do naravnega patiniranja. Vprašanje patine ima v zgodovini umetnosti in tudi konservatorstva dolgo zgodovino (Mellucco Vaccaro 1996, 366-371). Na področju kiparstva ima spreminjanje površine skulpture zaradi naravnega spreminjanja samega materiala posebno vlogo pri bronastih skulpturah, kjer bron naravno oksidira in spremeni barvo. $\mathrm{V}$ primeru kamnitih skulptur, posebno v naravnem okolju, pa se odpre paleta možnih deterioracij - te segajo od razpok, listanja, mehanskih poškodb, nalaganja depozitov do biološke kolonizacije (International Council on Monuments and Sites 2008; Doehne in Price 2010). Kamnite skulpture bodo prav tako potrebovale načrt rednega pregledovanja stanja ohranjenosti, čiščenja v primeru vandalizmov ter konservatorskih posegov v primeru večjih poškodb. Posebej bo pa potrebno definirati protokol glede obdelave in vzdrževanja površine kamna, ki bo sčasoma patiniral s pojavljanjem lišajev in mahov na površini.

V specifičnem primeru ne gre več za klasično dilemo med izvorno podobo umetniškega dela ter njegovo spreminjajočo se podobo zaradi naravnega spreminjanja materiala (Philippot 1966 v Price idr. 1996, 372) skozi življenje umetniškega dela, ki slednje prav tako oblikuje in tvori njegovo "avro« (Benjamin 2008). V konkretnem primeru je odločitev o vzdrževalnem pristopu tudi del izvornega koncepta umetnika/umetnice. Avtorica kamnitih skulptur, Špela Šedivy, je v intervjuju pojasnila, da je naravna patina skulptur del same interpretacije, ki jo je s skulpturami želela ustva- 
riti, in bi naravno patiniranje po potrebi celo spodbudila (elektronska korespondenca s Špelo Šedivy, 16. december 2020). Namen postavitve in oblike je namreč bil, da se od zunaj vneseni kamen "prepusti naravi«, da ga ta "sprejme« in se skulptura tako poveže $z$ okoljem. Ta zavestna odločitev in umetniški vzgib narekujeta ustrezno ravnanje, v okviru katerega se torej sprememb na površini kamna ne odstranjuje $\mathrm{z}$ značilnimi restavratorskokonservatorskimi pristopi (mehansko čiščenje, odstranjevanje $\mathrm{z}$ vodo, peskanje ipd.; Dolenec in Porekar Kacafura 2013, 3-8). Enak pristop je smiseln tudi za Pogačnikovo novo inštalacijo mandorle - maternice, oblikovane iz ostankov nekdanjega monolita Babe, ki so dejansko in situ najden material, ohranjen v neobdelani obliki, zgolj postavljen v novo prostorsko zasnovo. $\mathrm{V}$ obeh primerih kiparskih intervencij pa $\mathrm{v}$ vzdrževalna dela sodi ustrezno vzdrževanje in odstranjevanje vegetacije, ki bi čezmerno preraščala skulpture ter omejevala dostop in torej razumljivost del.

Preventivno vzdrževanje predstavlja "najvišjo obliko ohranjanja dediščine« (Feilden in Jokilehto 1998, 41) in ga zato umeščamo med poglavitne naloge upravljanja. Poleg vzdrževanja registrirane dediščine bo torej vzdrževanje obsegalo tudi kamnite skulpture, ob tem pa tudi kamnite pragove in kamnitih označevalcev.

\section{Krajina in naravne vrednote}

Pomemben, a izmuzljiv vidik upravljanja Mitskega parka predstavlja krajina - mitska krajina kot kategorija dediščine, ki je sicer primarno snovna, a ima dediščinski pomen zaradi nesnovne dimenzije. A njena ohranitev je neposredno povezana s konkretnim prostorom in z naravnimi vrednotami ter antropogenimi elementi v njem. Vprašanje se poraja, ali - in če, kako krajino kot celoto ohranjati in upravljati.

Kateri so torej naravni elementi krajine in kakšen status imajo? Širša površina območja parka $\mathrm{v}$ trenutnem občinskem podrobnem prostorskem načrtu Občine Hrpelje-Kozina sicer obsega gozdne površine in kmetijske površine. Neposeljeni del parka na vzhodu, v okviru t.i. »Lintverjevega kroga«, poleg najdišča Ajdovščina obsega šest točk v naravi. Pri teh gre večinoma za naravne elemente, ki so jim ljudje v preteklosti pripisali posebne pomene: Jezero na vršiču Čuk (kot domovanje kačona, lintverja) kot naravna oblika, ob njem pa so prepoznavne tudi geometrično dokaj pravilne strukture iz apnenca, ki so bile tja prinesene (Kovačič 2021); ledina Kobilja glava, kjer se nahaja kamen v obliki živalske lobanjske kosti (kjer naj bi po izročilu čarovnice ubile človeka); ledina Pod lisičino, kjer se nahajajo kamnita vdolbina v apnenčastem sloju (»hudičev stol«) ter raze v apnenčas- 
ti formaciji, ki jih pripovedno izročilo razlaga kot »šembiljine kolesnice«, ter lokacija vidnega stika fliša in apnenca (t. i. Sešica/Sušica) itd. Zahodni del parka, ki se nahaja na apnenčasti podlagi, pa sestavljajo kraške jame in doline, na katere se veže bogato izročilo o domovanju škratov, zmajev oziroma točkah vstopa v onostranstvo, torej smrti ali drugačni percepciji časa (Globoka jama, Cikova jama, Fukova jama).

Z zahodnimi točkami Babinega kroga (Globoka jama) park sega na varovano območje Natura 200o, varovano kot območje Kras in kot posebno ohranitveno območje (ID SI3000276) ter posebno območje varstva (ID SI5000023). Globoka jama (ID 47512) ima sicer status zavarovane naravne vrednote kot točke, enak status ima tudi Fukova jama (ali jama Majekavc; ID 411114). Cikova jama (ID 1319) ima status zavarovanega območja (točka) kot naravni spomenik lokalnega pomena. Posebna po dimenzijah je udornica Remeščica (imenovana tudi Rodiška pečina), o katere mitskem stvarjenju (ustvarila naj bi jo Jezus in sv. Peter) priča izročilo; ima status zavarovanega območja (ID 2050), hkrati pa je pripoznana kot naravna vrednota (točka) lokalnega pomena (ID 41125). Na širšem območju med točkami spodnjega dela parka (Babin krog) se nahaja še vsaj 15 točk naravnih vrednot, kraških jam. Skladno z Zakonom o varstvu podzemnih jam (z PVJ) (2004, 11., 25. in 26. člen) mora vsaka od teh imeti predvidenega skrbnika. Številna določila pa postavljajo temelje za njihovo varovanje, kot so varstveni režim glede prepovedanih dejavnosti v jami; omejevanje obiska v odprtih jamah in nadzor vstopa v jamo; morebitna gradnja objektov ob jamah, s katero se posredno regulira tudi dejavnost na površju. Varstvo narave, predvsem pa varstvo podzemnih jam predstavlja pomemben vzvod ohranjanja in varovanja snovnih elementov mitske krajine, a zgolj kot točk. Opozorimo, da mora torej upravljanje parka ustrezno uskladiti zahteve varstva podzemnih jam ter predvidenih interpretacijskih dejavnosti neposredno $v$ njihovih okolici.

\section{Mitska krajina kot kulturna krajina}

Kako torej upravljati mitsko krajino kot krajino? Kulturna krajina je običajno definirana kot rezultat interakcije med človekom in naravo, ki naj bi odsevala plastenje oz. razvoj skozi čas (Taylor, St Clair in N. J. Mitchell 2014, 5) in funkcionira kot palimpsest. Sodobne študije preizprašujejo smiselnost ločevanja med naravno in kulturno krajino ter izpostavljajo predvsem asociativno dimenzijo krajine zaradi pomena, ki ga nosi za posamezne skupnosti.

Temeljni evropski dokument za upravljanje krajine, Evropska konven- 
cija o krajini (200o), je ta koncept privzel in krajino definiral kot »območje, kot ga zaznavajo ljudje in katerega značilnosti so plod delovanja in medsebojnega vplivanja naravnih in/ali človeških dejavnikov«. Bistveno je, da ne razločuje med "naravno« in »kulturno « krajino, temveč izhaja iz prepletenosti elementov v njej, velik pomen pa pripisuje "zaznavanju « krajine $s$ strani skupnosti (Pirkovič 2017, 31). Posledično je ponovno skupnost, povezana $z$ dotično krajino, tista, ki ima (bi morala imeti) glavno vlogo v njenem upravljanju.

Slovenski kulturnodediščinski varstveni okvir vsebuje koncept kulturne krajine, a je ta izrazito usmerjen v njeno snovnost. Dediščinska zakonodaja kulturno krajino tolmači kot (Pravilnik o seznamih zvrsti dediščine in varstvenih usmeritvah 2010 , 3. člen, 8. točka) del odprtega prostora z naravnimi in grajenimi ali oblikovanimi sestavinami, katerega strukturo, razvoj in rabo pretežno določajo človekovi posegi in dejavnosti, ki soustvarjajo posebne kulturne in družbene vrednote in identiteto regij ter države. Kulturna krajina je rezultat součinkovanja človeških in naravnih dejavnikov ter je odraz in primer gospodarskega, kulturnega, socialnega, političnega in tehnološkega razvoja družbe. Glede na strukturne značilnosti in krajinske sestavine ločimo kmetijske krajine, poseljene krajine in zgodovinske krajine.

Kot potencialne varovane vrednote pa Pravilnik o seznamih zvrsti dediščine in varstvenih usmeritvah navaja snovne elemente: krajinsko zgradbo in prepoznavno prostorsko podobo, značilno obstoječo parcelno strukturo, velikost in obliko parcel ter členitve, tradicionalno rabo zemljišč, tipologijo krajinskih sestavin in tradicionalnega stavbarstva, odnos med krajinsko zgradbo in stavbo oziroma naseljem, avtentičnost lokacije pomembnih zgodovinskih dogodkov, preoblikovanost reliefa in spremljajoče objekte, grajene strukture, gradiva in konstrukcije ter likovne elemente in zemeljske plasti z morebitnimi arheološkimi ostalinami (Pravilnik o seznamih zvrsti dediščine in varstvenih usmeritvah 2010, 4. člen, 8. točka). Sodobne raziskave sicer kažejo, da kulturna krajina zaradi svojega imanentno dinamičnega značaja, ki - tako kot živa nesnovna dediščina - temelji na kontinuiranem spreminjanju, ne more biti vrednotena $\mathrm{z}$ enakimi merili kot neprimerljivo statičnejša nepremična (stavbna ali arheološka) dediščina (Lah 2018). A tudi nova predlagana orodja so usmerjena predvsem $v$ snovne vidike, kot so analiza strukture (povezave, površine, volumni) ter posameznih materialnih ostankov (Lah 2018). Slovenski kulturnodediščinski okvir tako (še) ne ponuja orodja za ustrezno vrednotenje in ohranjaje mitske krajine. Potencialno pa se pot za to lahko odpre znotraj kategorije zgodovinske 
krajine in v povezavi s konceptom krajev spomina (fr. lieux de memoire; cfr. Pirkovič 2017, 34).

Mednarodni strokovni kontekst ponuja več opcij. V okviru U N E S C O-ve svetovne dediščine je kulturna krajina splošno definirana kot »combined works of nature and of man" (U NESCO 2019, 83). UNES CO-va konvencija kulturno krajino deli v tri kategorije: oblikovano naravo (parki, vrtovi ipd.); organsko razvito krajino, ki se dalje deli v »reliktno « ali »fosilno krajino « (ki se ne razvija več) in »kontinuirano krajino « (ki se še naprej spreminja skozi interakcijo med naravo in človekom); »asociativno krajino" (povezana $\mathrm{z}$ verskimi, umetniškimi ali kulturnimi pomeni). Izmed treh kategorij je asociativna krajina tista široka kategorija, ki - poleg lokacij zgodovinskih dogodkov, z umetnostjo in z religijami povezano krajino ipd. zajema tudi mitsko izročilo, mite, folkloro (Dumbović Bilušić 2015, 184). Rodiško mitsko krajino tako uvrstimo med asociativne krajine zaradi neposredne povezave s pripovednim izročilom. Pomembno je poudariti, da je izmed treh kategorij kulturnih krajin prav asociativna krajina tista, kjer je antropogeni element neznaten ali ga celo ni, pomen krajine pa je neposredno povezan zgolj z naravnimi elementi, na katere se asociativnost veže (Dumbović Bilušić 2015, 181).

Čeprav je asociativni vidik, v najširšem smislu, v ospredju sodobnih definicij kulturne krajine, pa je ta najpogosteje izpostavljen $v$ izvenevropskih kontekstih, kjer so prisotne staroselske kulture. Kot emblematični primer asociativne krajine je množično navajani primer narodni park Uluru-Kata Tjuta v Avstraliji, ki ga že 35 let upravlja aboriginska staroselska skupnost Anangu. Območje monolita iz peščenjaka je izjemnega pomena kot nesnovna dediščina, saj je za staroselsko skupnost krajina rezultat delovanja njenih človeških in mitskih prednikov. V razvoju konservatorstva kulturne dediščine je Uluru pomembna prelomnica, saj je iz zgolj naravne znamenitosti postal renominiran tudi kot kulturna dediščina ter predan v upravljanje tradicionalni skupnosti (Rössler 2014, 32-33). V evropskem kontekstu je tovrstna predkrščanska, »staroselska« vez z naravo izgubljena, zato primerljivih vzorov dediščine ne njihovih sistemov upravljanja ni. Relativno primerljiva z zahodnim kontekstom je Japonska, kjer je tradicionalna kultura še izrazito živa, a sobiva s sodobnim globalnim načinom življenja. $\mathrm{Na}$ Japonskem je bil koncept kulturne krajine, ki v veliki meri temelji na asociativnih vrednotah, uveden že v sredini sedemdesetih let, ključni vzvod njenega varovanja pa je prostorsko načrtovanje (Inaba 2012).

Navedene tri U N E S C O-ve kategorije pa so prenesene v slovenske zakonske in strokovne podlage s področja prostorskega razvoja, a so mestoma 
drugače razložene. Prav asociativna kulturna krajina je sicer skoraj identično razložena kot tista oblika, "v kateri[h] prevladujejo izrazite religiozne, umetniške ali kulturne povezave $\mathrm{z}$ naravnimi prvinami« (Odlok o strategiji prostorskega razvoja Slovenije (od S P RS) 2004). A specifičnih navodil glede njenega varovanja ni najti. Kategorije $\mathrm{v}$ rabi so primarno usmerjene v snovne vidike: »dediščinska kulturna krajina«, ki je definirana kot »kontinuirana kmetijska raba zemljišč ali materialne ostaline, ki odražajo preteklo rabo zemljišč, dejavnosti, spretnosti in tradicijo « (Odlok o strategiji prostorskega razvoja Slovenije (Od S P RS) 2004; Bevk idr. 2020, 52), in sovpada s kulturnodediščinskim konceptom; »izjemna krajina«, ki temelji na elementih edinstvene rabe tal, ustreznega deleža naravnih prvin in/ali posebnega naselbinskega vzorca (na nacionalnem ali lokalnem nivoju); ter »območja in prvine krajinske prepoznavnosti«, ki jih določajo »kakovostne, izjemne ali značilne prostorske strukture, odvisne od tipoloških značilnosti krajine ter so pomembne za prepoznavnost prostora in jih je zato treba ohranjati, nadgrajevati ali sanirati (Bevk idr. 2020, 52-53). Izpostavimo, da je med dejavniki za prepoznavnost krajine najti tudi dva, ki odpirata prostor za nesnovne vidike: avtentičnost in pričevalnost krajinske zgradbe ter zgodovinski ali simbolni pomen posameznih delov ali celote (Hudoklin, Selak in Simič 2005, 4). Simbolni pomen lahko izhaja iz naravnih ali kulturnih prvin, vrednoti pa se glede na nacionalno, regionalno in lokalno (str. 1213). Lokalno pomembna območja prepoznavnosti se določajo glede na šest meril, med katerimi rodiška mitska krajina odgovarja vsaj sledečim: številčnosti in kvaliteti naravnih vrednot ter prostorsko pomembne kulturne dediščine (če štejemo številne evidentirane jame), povezanosti naravnih vrednot in kulturne dediščine (zelo konkretna povezava med jamami in nesnovno dediščino), prostorski pomembnosti in prispevku $\mathrm{k}$ identiteti prostora (mitsko izročilo kot topos kolektivnega spomina Rodičanov). Naj k temu dodamo, da bi tovrstno vrednotenje moralo izhajati iz vrednotenja (tudi) lokalne skupnosti.

Del Brkinov in Matarskega podolja (na področju Občine Ilirska Bistrica) že sodi med krajinska območja s prepoznavnimi značilnostmi, ki so pomembna na nacionalni ravni (Odlok o strategiji prostorskega razvoja Slovenije (OdS P R S) 2004). Potencialna razširitev na celotne Brkine, vključno z Rodikom, bi lahko pomembno prispevala k ohranjanju snovnih elementov mitske krajine. Splošne usmeritve zadevajo tako posege v antropogene (ustrezna razmestitev funkcionalnosti, stik naselja z odprto krajine, skladno umeščanje novih elementov ...) kot naravne elemente (preprečevanje zaraščanja na kmetijskih površinah, preprečevanje poseganje v gozdne po- 
vršine itd.). Prostorska zakonodaja torej ponuja najoprijemljivejše vzvode za celovitejše vrednotenje in upravljanje mitske krajine, a ostaja problem vključevanja asociativnih, nesnovnih vidikov.

\section{Nesnovna dediščina}

Mitsko krajino sestavljajo tako nesnovno ustno izročilo kot tudi konkretni prostori, predvsem naravna okolica in antropogeni elementi, o katerih to izročilo govori oziroma se nanje navezuje. Pripovedno izročilo prikazuje mitski izvor kraja, prebivalcev in krajine ter njenih naravno-geografskih značilnosti. Trenutno ta bogati korpus rodiške nesnovne kulturne dediščine nima statusa zaščitene nesnovne kulturne dediščine.

Nesnovna dediščina je v kratkem času od uradne legitimacije z U N E S C Ovo konvencijo leta 2003 dobila orodje za vrednotenje in osnovne usmeritve za upravljanje. Obstoječa literatura o upravljanju kulturne dediščine in snovanju načrtov upravljanja se primarno posveča snovni dediščini, nesnovni elementi pa $\mathrm{v}$ tem okviru dobijo mesto $\mathrm{v}$ okviru interpretacije. $\mathrm{V}$ UNE S C O-vi konvenciji o nesnovni dediščini iz leta 2003 naloge upravljanja niso točno zapisane, saj je upravljanje specifične prepoznane vrednote stvar vsakokratnega procesa vrednotenja dotične skupnosti nosilcev te dediščine. Ta odnos odseva osnovno pozicijo konvencije, $\mathrm{v}$ čemer se ta temeljno razlikuje od "sestrske« konvencije o varstvu svetovne kulturne in naravne dediščine (1972), ki stremi k hierarhičnemu prepoznavanju izjemne vrednosti (angl. outstanding universal value) določenih enot dediščine. Obratno konvencija o nesnovni dediščini slednjo "prepoznava po pomenu, ki [ga] ima ta dediščina za identiteto, občutek pripadnosti in kontinuiteto skupnosti, kjer nastaja in kjer jo prenašajo na naslednje generacije (Spanžel 2012, 13). Uspešno in ustrezno upravljanje nesnovne dediščine je tesno povezano $\mathrm{z}$ ohranjanjem skupnosti nosilcev te dediščine oz. zagotavljanjem in izboljševanjem pogojev za njeno ohranitev oz. obstoj. Posledično za nesnovno dediščino niso bili oblikovani priročniki za njeno upravljanje, temveč register dobrih praks (Židov 2014).

V slovenskem kontekstu je upravljanje nesnovne dediščine definirano $z$ dvema členoma Pravilnika o seznamih zvrsti dediščine in varstvenih usmeritvah (2010, 8. člen); prva točka pojasnjuje, da: »(1) [v]arstvene usmeritve za živo ${ }^{2}$ dediščino vključujejo ukrepe za zagotovitev ohranjanja žive dediščine, ki obsegajo prepoznavanje, dokumentiranje, raziskovanje, zaščito,

\footnotetext{
${ }^{2}$ V slovenski zakonodaji je v rabi termin »živa dediščina«, kar pa je v strokovnih in znanstvenih besedilih označeno kot »nesnovna dediščina«. Več o tem v Židov (2014).
} 
spodbujanje, izboljševanje in oživitev različnih vidikov te dediščine. Konkretnejše varstvene usmeritve se določijo na podlagi stanja oziroma ohranjenosti pojava dediščine, ki se deli na nepretrgano, rekonstruirano in izginulo dediščino. "Druga točka pa izpostavi vodilni pomen nosilcev pojava oz. dediščine, obenem pa tudi materialne prvine (predmeti, orodja, izdelki) in prostor, kjer se nesnovna dediščina ustvarja ali izraža, in se tako naveže na temeljni koncept konvencije.

$\mathrm{Na}$ primeru Rodika je potrebno najprej razjasniti, s kakšno vrsto nesnovne dediščine imamo opravka. Slovenski register nesnovne dediščine se naslanja na kategorizacijo, po kateri je oblikovan reprezentativni seznam U NE S C O-ve nesnovne dediščine, ki obsega pet kategorij: ustno izročilo in ljudsko slovstvo, uprizoritve in predstavitve, šege in navade, znanja o naravi in okolju, gospodarska znanja in veščine ter kategorijo "ostalo« (ki je mednarodni okvir nima). V Rodiku se soočamo s konceptom »mitske krajine«, ki je v svojem bistvu sinteza ustnega izročila in elementov v krajini. $S$ formalnega vidika so "rodiške pravce« pripovedno izročilo, $z$ vsebinskega vidika pa imamo $z$ več vidikov opravka s kategorijo "znanja o naravi in okolju«, saj številne od ohranjenih "pravc« pojasnjujejo vremenske pojave (dvig Babinega krila kot metafora za razjasnitev po dežju; lintverjeva jeza kot nastanek strel) in vsebujejo razlage naravnih pojavov (jame).

\section{Nosilci nesnovne dediščine}

Glede na uveljavljene smernice ohranjanja in upravljanja nesnovne dediščine se poraja več vprašanj. Kot že rečeno, je nesnovna dediščina primarno povezava s krajem in kontekstom, kjer se udejanja. Ključni dejavnik ohranjanja so živi nosilci dediščine (posamezniki ali skupine) in torej skupnost, ki je prvi skrbnik in varuh dediščine. U N E S C O-v register dobrih praks ohranjanja in upravljanja izpostavlja tiste primere, kjer se ohranjanje nesnovne dediščine vpenja $v$ trajnostno upravljanje celotnega kulturnega in naravnega ekosistema, kjer dotična dediščina aktivno »živi“ (Proschan 2008). Nosilci nesnovne dediščine imajo torej ključno vlogo pri ohranjanju in promoviranju dediščine; kjer nosilci niso več živi, se dokumenti (avdioin videoposnetki, zapisi) te "izginule« dediščine ohranjajo v okviru ustanov (inštitutov, muzejev, parkov) (Draženović in Smrekar 2020). Kakšno je stanje v Rodiku? Jedro rodiške nesnovne dediščine primarno tvori pripovedno izročilo, ki ga je leta 2000 zapisala Jasna Majda Peršolja v knjigi Rodiške pravce in zgodbe, ob tem pa tudi ustno izročilo redkih informatorjev, ki jih je zabeležila etnologinja Katja Hrobat Virloget. Ta vidik razumevanja in posledično potencialne ogroženosti je eden bistvenih, če bi želeli 
rodiško mitsko izročilo zaščititi z vpisom v register. Pogoj je, da ima dediščina zagotovljen prenos, torej nosilca te dediščine, v Rodiku torej pripovedovalca. V okviru Mitskega parka bo to pripovedno izročilo dobilo novo obliko življenja kot del interpretacije $\mathrm{v}$ parku in centru za obiskovalce: kot zapisano na panojih, posneto na avdiovodnikih, predvsem pa predano $\mathrm{v}$ živo preko vodnikov in metode storytellinga. Kot opozarja K. Hrobat Virloget (2019, 34; 2021), se ob tem poraja vprašanje, ali tovrstno ohranjanje bodisi preko tiskane knjige, posnetega avdiovodnika ali profesionalno zaigranega storytellinga - sploh odgovarja konceptu ohranjanja nesnovne dediščine. Ko je ujeto na nek fizični nosilec, ta »živa«, spremenljiva dediščina zamrzne. Kaj je torej bistveno za ohranjanje te dediščine?

\section{Pripovedno izročilo kot ljudsko slovstvo}

Ob tem si velja pobliže pogledati, katere so sestavine, ki definirajo ustno izročilo pripovedništva, saj te tvorijo tudi elemente, ki jih (lahko) ohranjamo. Pripovedno izročilo sestavljajo trije temeljni elementi: tekst (besedilo), tekstura (način podajanja, pripovedovanja oz. izvedba) in kontekst (okolje, kjer je pripovedovano, vključno $\mathrm{z}$ občinstvom) (Stanonik 2001, 117). Ključno vlogo ima povezovalec treh elementov, to je pripovedovalec, pravljičar. V preteklosti - in v primeru Rodika še danes - so to bili nadarjeni posamezniki, ki so z lastno pripovedovalsko noto in dramaturgijo interpretacijo preoblikovali ter torej predajali sporočilo fabule (zgodbeno ogrodje), ki se je ohranila skozi rodove. Folklorno pripovedovanje je torej tipičen primer stalnega predrugačenja in inovacije $v$ nesnovni dediščini, saj je inovacija nujno prisotna, kaže pa se v nedrznih posegih $\mathrm{v}$ vsebino, ki sicer sledi tradiciji (Štefan 1999, 6-7).

V primeru Rodika lahko ugotovimo, da vendarle obstaja še nekaj pripovedovalk, ki to izročilo znajo prenašati na značilni ustni način (babica - vnuki). Gre za starejše Rodičanke, ki še živijo v vasi, a tudi tiste, ki so se preselile v lokalna urbana središča (npr. Koper), vendar izročilo ohranjajo v razširjenem družinskem krogu. Ta prenos še ni raziskan, a bi bila tovrstna raziskava smiselna predvsem zato, da se preveri, ali se sodobno pripovedovanje izvaja na osnovi natisnjenih "rodiških pravc" ali gre za živo izročilo preteklih generacij. K. Hrobat Virloget sicer opozarja (2019, 34-35), da glavni prenašalci rodiškega izročila umirajo, za njimi pa ostaja vrzel. Vprašanje pa se poraja tudi glede konteksta folklornega pripovedništva: okolje, v katerem se lahko izročilo prenaša, se je bistveno spremenilo. Če so nekoč ustno izročilo prenašali od ust do ust (Stanonik 2001, 118-119), ob vsakodnevnih opravilih in za krajšanje časa, je danes ta kontekst bistveno 
spremenjen. Njegova bistvena elementa sta domače okolje in pa predvsem publika, ki s pripovedovalcem stopa $\mathrm{v}$ interakcijo, njegovo pripoved spodbuja, pripovedovalec je do nje dovzeten, se nanjo odziva (Štefan 1999, 134140). Publiko so običajno tvorili otroci in starejši (Žele 2003, 26), a nadarjeni pravljičar je lahko navdušil tudi odrasle. Ciljna skupina/publika so sicer še danes predvsem otroci.

Poleg omenjenega prenašanja v intimnem okviru družine je velik del prenosa izročila prenesen na institucionalno raven, $v$ okviru šolskih dejavnosti, $\mathrm{z}$ branjem, izjemoma pa tudi $\mathrm{z}$ gostovanji pravljičarjev in pravljičark $\mathrm{v}$ šolah ali preko tematskih dni izven šole. Slednje se z vzpostavitvijo parka vrši tudi v Rodiku. Ob tem je potrebno opozoriti še na drugi način obujanja nesnovne dediščine, in sicer prav preko prevzemanja rezultatov znanstvenih raziskav, na podlagi katerih se na novo vzpostavljajo prakse med lokalnim prebivalstvom kot rekonstrukcije nekdanjih, izginulih praks (Hrobat Virloget 2019, 32).

\section{Folklorizem in storytelling}

Odpira se torej vprašanje odnosa do folklorizma, torej oživitve tradicije izven izvornega konteksta in okolja oz. "posredovanje in predstavljanje kulture iz druge roke« (Moser 1962 v Istenič Poljak 2008, 62). A prav trajnostni vidik upravljanja in ohranjanja nesnovne dediščine briše mejo med tradicijo in folklorizmom. S tem ko je upravljanje mitskega parka v Rodiku prevzela lokalna skupnost in kot vodnike po parku vključila lokalne prebivalce, so bile $\mathrm{v}$ to dejavnost vključene tudi osebe, ki v svojem osebnem življenju v intimnem krogu družine prenašajo rodiško ustno izročilo, torej sodobni pripovedovalci. Ciljno publiko v mitskem parku pa tvorita dve glavni kategoriji: šolske skupine in obiskovalci (izletniki, turisti); med šolskimi skupinami prvo ciljno kategorijo predstavljajo lokalne osnovne šole iz kraško-brkinske regije. Fragmentarno se torej ohranjajo posamezni elementi folklornega pripovedništva, a v preoblikovanem kontekstu. Vez s tradicijo še ni povsem pretrgana, posvetiti se je zato potrebno prav tistim elementom, ki so še živi, in jim omogočiti, da se razvijajo dalje. Ob tem se izostri pomen interpretacije dediščine, natančneje osebne interpretacije skozi storytelling oz. »umetnost pripovedovanja (Draženović in Smrekar 2020, 60); slednja si namreč z ljudskim pripovedništvom deli več elementov (vloga pripovedovalca, dramaturgija zgodbe, pripovedovanje kot umetniško ustvarjanje).

Prepoznavamo torej več elementov folklornega pripovedništva, ki se ohranjajo, a hkrati smo nedvomno priča prenosu izvorne funkcije in gra- 
diva $\mathrm{v}$ nov kontekst. A prav s tem prenosom se pomemben del izvornega korpusa dediščine ohranja. Nenazadnje, v mednarodnem kontekstu ohranjanja nesnovne dediščine je storytelling termin, ki označuje kategorijo nesnovne dediščine; njena ohranjanje in razvoj pa se promovira preko festivalov. Primer dobre prakse v evropskem kontekstu je program "Land of Legends« v švedski regiji Kronoberg (U N E S co b.l.b). Malenkost bolj oddaljen, a za Rodik relevanten je tudi primer ustnega izročila kirgizijskih epskih pripovedovalcev, ki se ohranja $z$ vzpostavitvijo študijskih centrov, kjer bi potekal horizontalen in vertikalen (medgeneracijski) prenos znanj, ter digitalnega arhiva (U N E S C O b.l.c). Bistvena naloga upravljanja pa je v tem oziru ustrezno usmerjanje dela vodnikov in podajanje jasnih smernic stran od banalizacije nesnovne dediščine. Slednja je poleg zamrzovanja in poblagovljenja namreč ena od bistvenih prepoznanih groženj za nesnovno dediščino (Pukl 2012, 28; Židov 2014), ki jo lahko zajezi ustrezen strokovni nadzor nad podanimi vsebinami (Hrobat Virloget 2019, 36). V ta namen so bili v okviru projekta »Mitski park" oblikovane smernice za interpretacijo mitske krajine (Hrobat Virloget 2021) ter izvedena izobraževanja za vodnike. Slednja so vsebovala tako izobraževanja o sami vsebini ustnega mitskega izročila kot znanja o njihovi strokovni razlagi.

\section{Pomen za lokalno skupnost}

Mednarodno promovirani primeri dobrih praks ohranjanja in upravljanja nesnovne dediščine se posvečajo primarno tradicionalnim skupnostim, smisel ohranjanja nesnovne dediščine pa je, kot že rečeno, trajnostni razvoj skupnosti, torej ohranjanje njene kulturne in ekonomske podstati. UNESCO-v register dobrih praks za varovanje nesnovne kulturne dediščine, ki je namenjen izmenjavi najboljših praks in mednarodnemu povezovanju, kot vzor izpostavlja npr. živi muzej glasbe Fandanga v Braziliji, preko katerega se je opolnomočila in ekonomsko ponovno vzpostavila lokalna skupnost (UNESCO b.l.a). Za upravljanje nesnovne dediščine je tako na prvo mesto postavljen pogoj, ki je eden izmed temeljev tudi pri upravljanju snovne dediščine - to je vključenost lokalne skupnosti v procese odločanja (Wijesuriya, Thompson in Young 2013; Plestenjak in Stokin 2016, 13). Samo aktivna vloga lokalne skupnosti omogoča vzdrževanje in ohranjanje dediščine ter spomenikov na lokalni ravni. Lokalna skupnost pa ima od tega tudi neposredne in posredne koristi, od dobička od vstopnin in prodaje spominkov do trženja lokalnih izdelkov in povečanega obiska gostinskih objektov, posebej pa je treba izpostaviti širši razvoj kulturnega turizma $z$ urejanjem infrastrukture (kolesarske in pohodniške poti), raznovrstno po- 
nudbo lokalne hrane in s povezavo $\mathrm{z}$ naravnimi znamenitostmi. Vsi ti vidiki so prisotni v primeru Rodika; vključenost lokalne skupnosti se izkazuje v že omenjenem predvidenem sistemu upravljanja, kjer pomembno vlogo igra lokalno Turistično društvo. Jasna podpora in udeležba lokalne skupnosti v vzpostavitvi parka sta se pokazali že v času njegove priprave, ko so lokalni prebivalci dovolili, da se na zasebnih parcelah postavijo označevalci (Hrobat Virloget 2019, 32), s pomočjo pri pripravljalnih delih v parku in $\mathrm{z}$ udeležbo na tečajih za vodnike. S tem si lokalna skupnost postavlja temelje za trajnostni razvoj kraja - s čimer pa se neposredno približamo izhodiščni ideji o smiselnosti in ciljih ohranjanja nesnovne dediščine, kot jo promovira UNESCO. Kot vzvod proti banalizaciji, pa je - kot že omenjeno $\mathrm{v}$ prvih poglavjih - ključnega pomena, da se ohrani stalni stik med etnološko stroko in upravljavci.

\section{Čezmejnost}

Poseben izziv v upravljanju Mitskega parka v Rodiku pa predstavlja čezmejna povezava z mitološko tematsko potjo v Mošćenički Dragi, s katero skupaj tvorita čezmejni mitski park. Najprej je potrebno pojasniti, za kakšno vrsto čezmejnosti gre, pri čemer nam ponovno pomaga delovni okvir UNESCO-ve svetovne dediščine. V tem okviru namreč ločuje transboundary oz. transnational sites (čezmejna oz. transnacionalna območja), torej večja območja, ki bodisi prečijo državne meje oz. so vsebinsko povezana, a se nahajajo $\mathrm{v}$ oddaljenih državah. Ob tem pa obstaja tudi kategorija serial nominations (serijski vpisi dediščine), s pomočjo katere se spomeniki ali območja iste tematske skupine vpisujejo v skupni dosje. Ti se lahko nahajajo znotraj ene države ali več različnih držav, tovrstni primeri so alpska prazgodovinska kolišča, rimski limes v Evropi, stećci ipd. Nastajajoči Čezmejni mitski park bi po svojih značilnostih sodil v kategorijo transnacionalnega serijskega vpisa. U N E S c O-ve operativne smernice dajejo jasna navodila: tako za čezmejne kot serijske primere je ključnega pomena oblika upravljavskega sistema. Za čezmejna območja je bistven skupni upravljavski odbor (angl. Joint Management Committee) (U N E S C O 2019, 39), za serijske vpise pa je potrebno koordinirano upravljanje (str. 32) sicer ločenih upravljavskih teles. Za transnacionalna serijska območja se priporoča oblikovanje medvladnega dogovora glede upravljanja. Naloge skupnega ali vsaj koordiniranega upravljanja so: usklajevanje različnih jezikov in institucionalnih kultur, vključno z lokalnimi skupnostmi, zagotavljanje participatornosti v upravljanju ter prezentiranje (interpretiranje) pomena serijskih spomeniških območij širši javnosti (U N E S CO 2010, 4). 


\section{Primeri čezmejnih oblik upravljanja}

Na območju Slovenije in Hrvaške čezmejnost sama po sebi ni noviteta, saj imamo takih primerov več. $\mathrm{V}$ praksi poznamo več oblik čezmejnih enot - od serijskih in transnacionalnih U NESCO-ovih lokacij (npr. prazgodovinska alpska kolišča) in večjih čezmejnih geoparkov (npr. UNESCO-ov globalni Geopark Karavanke/Karawanken ${ }^{3}$ ) do čezmejnih parkov (park Isonzo/Soča ${ }^{4}$ ). Usmerjen v mitsko krajino je bil tudi projekt Interreg »Living landscape«, v okviru katerega je bil na idejni ravni zasnovan že mitskofolklorni park, ki naj bi povezoval Gropado v Italiji in Rodik v Sloveniji (Hrobat Virloget in Kavrečič 2015) in predstavlja referenco za izvedeni Čezmejni mitski park. Del rezultatov pa je vključen v nastajajoči Geopark Kras (izvedba predvidena za leto 2022).

Pomemben vzor čezmejnega upravljanja kulturne dediščine predstavlja dvojni projekt (Claustra ${ }^{5}$ in Claustra+), posvečen Claustra Alpium Iuliarium, ostankom rimskega alpskega zidu na slovenski in hrvaški strani meje (Nikolić Đerić 2018). Cilj projekta je bil vzpostaviti čezmejno upravljanje arheološke dediščine, torej jasno opredeljenih prostorskih grajenih enot, ki so historično tvorile enotno prostorsko strukturo na večjem teritoriju. Kljub očitnim razlikam glede na Mitski park pa projekta ponujata pomembno referenco za opredelitev skupnih elementov upravljanja. Projekt Claustra+ je povezal 19 točk v prostoru na obeh straneh meje. Zastavljene in izpeljane so bile skupne naloge: skupne preventivne raziskave izbranih arheoloških najdišč, skupna priprava čezmejnega konservatorskega načrta in čezmejnega načrta upravljanja, izvedba participativnih delavnic na obeh straneh meje, priprava skupnega promocijskega materiala (turistični vodnik, brošura, zloženka, dokumentarni in promocijski film ipd), ki je del komunikacijskih dejavnosti. V nadgrajevalnem projektu Claustra+ pa je bil zasnovan razvoj turističnega proizvoda Claustra, ki je obsegal oblikovanje smernic za razvoj in načrt promocije proizvoda, oblikovanje kulturno-turistične poti in povezanih itinerarijev, razvoj in izvedbo programa za obiskovalce, ki vključuje vzpostavitev čezmejnega konzorcija za povezovanje deležnikov in lokalnih gospodarskih subjektov, ter sistematično skupno promocijo proizvodov. Prepoznamo torej stremljenje ne zgolj h koordiniranemu ločenemu upravljanju, temveč dejansko skupnemu upravljanju. Posebna pozornost je bila v projektu Claustra posvečena vključevanju lokalnih skup-

\footnotetext{
${ }^{3}$ Glej https://www.geopark-karawanken.at.

${ }^{4}$ Glej https://www.ita-slo.eu/sl/isonzo-soča.

${ }^{5}$ Glej https://claustra.org.
} 
nosti, ki so bile aktivno vključene v prezentacijo in participativno vzdrževanje arheološki ostalin na izbranih lokacijah. Na obeh straneh meje je bila vzpostavljena enotna interpretacijska infrastruktura. Projekt Claustra se danes umešča med uspešnejše primere upravljanja in interpretacije dediščine v širši regiji.

\section{Elementi skupnega upravljanja mitskega parka}

Specifika Čezmejnega mitskega parka ni le v zvrsti dediščine, nesnovni dediščini, temveč v sami obliki nesnovne dediščine. Tako v Rodiku kot v Mošćenički Dragi govorimo o mitski krajini, le da je slednja na hrvaški strani ohranjena zgolj skozi toponime (vrh Perun, vas Trebišće, naselje Volosko) in zelo redke povedke, ki nakazujejo na predkrščansko slovansko mitologijo (Hrobat Virloget 2021). Edini jasni vezni član med lokacijama je povezava med likom Babe (prisotna v Rodiku) in likom Peruna (prisoten v Mošćenički Dragi), ki v slovanski mitologiji tvorita božanski par. Tako slovenska kot hrvaška lokacija se neposredno navezujeta na naravne vrednote $\mathrm{v}$ krajini, a elementi dediščine so bistveno različni, kar temeljno vpliva na določanje skupnih točk upravljanja. V obeh primerih je oblikovana tematska pot, le da je na hrvaški strani ta obstajala že od prej, a se zaradi pomanjkanja konkretnih elementov v krajini ni navezovala na konkretne lokacije. V okviru projekta je bilo zasnovano enotno interpretacijsko orodje inovativnega avdiovodnika, ki obstoječo hrvaško pot, opremljeno s klasičnimi lesenimi tablami, dopolnjuje. Bistvena skupna točka je torej enoten pristop $v$ interpretaciji nesnovne dediščine. Ta je definiran $z$ že omenjenimi skupnimi smernicami, ki stremijo k preprečevanju banalizacije nesnovne dediščine. Prav tako je bil vzpostavljen enoten načrt za prilagajanje vsebin za osebe $z$ omejitvami (slepi, slabovidni, gibalno omejeni), z enotnim pristopom pa je bil oblikovan tudi animacijski program za otroke. Zaradi skopo ohranjenega mitskega izročila v Mošćenički Dragi obstaja nevarnost, da se bo zaradi potrebe po prepoznavnosti parka pri interpretaciji dediščine pretirano uporabljalo zaigrano avtentičnost, $s$ čimer se lahko zapade $\mathrm{v}$ banalizacijo in diznifikacijo, ki dediščino razvrednotita.

Vsaka lokacija ima lastno upravljavsko strukturo: v Rodiku je to režijski obrat Občine, v Mošćenički Dragi pa Turistička zajednica Mošćenička Draga v sozvočju s tamkajšnjo občino. Pomemben element skupnega upravljanja je tudi promocija turističnih paketov, to je različnih oblik enoali večdnevnih obiskov za različne ciljne skupine, ki vključujejo tudi namestitev pri lokalnih turističnih ponudnikih.

Smiselni skupni elementi, ki bi lahko bili vključeni v oba načrta upravljanja, da zagotovijo čezmejni značaj Mitskega parka, bi morali obsegati: 
- enakovredno obravnavno ter vrednotenje nesnovne dediščine po enotnih kriterijih;

- določitev skupne vizije ter strateških in izvedbenih ciljev;

- skupno določitev kazalnikov;

- določitev interpretacijskega koncepta in posledično interpretacijskega pristopa;

- skupno in usklajeno izobraževanje vodnikov, turističnih operaterjev in lokalnega prebivalstva;

- usklajeno vključevanje lokalnega prebivalstva;

- usklajeno nadaljevanje raziskav in zbiranje morebitnega etnografskega gradiva;

- enotno celostno grafično podobo in enoten promocijski material za obe lokaciji;

- skupno oblikovanje turističnega produkta za potrebe promocije in trženja parka;

- usklajeno beleženje obiska na obeh lokacijah;

- skupno planiranje spremljevalnega programa vsaj za morebitne skupne dogodke;

- povezano izvajanje monitoringa;

- skupno evalvacijo.

Nekatere od naštetih točk so bile že izvedene v času vzpostavljanja parka: smernice za enoten interpretacijski pristop, skupna izobraževanja, C G P, promocijski material, skupni turistični produkt.

Prvih pet let po zaključku projekta bosta obe lokaciji čezmejnega parka postavljeni pred izziv upravljanja parka brez profitne dejavnosti, saj se po načelih razpisa rezultati projekta $v$ tem obdobju ne smejo tržiti (vstop in ogleda parka in razstav v centru za obiskovalce bosta brezplačna). Viri financiranja bodo izhajali iz proračunskih sredstev občine, morebitnih sponzorstev in drugih projektov. Financiranje bo pogojevalo tudi kadrovsko zasedbo, ki bo izvajala redne dejavnosti v parku (vodenje centra za obiskovalce, vzdrževanje infrastrukture v parku, vzdrževanje naravnih vrednot, promocija in komunikacija, organizacija dogodkov).

\section{Sklepna diskusija}

Predstavljena analiza je pokazala, da je upravljanje mitske krajine poseben izziv zaradi elementov, ki jo sestavljajo. Na primeru Rodika se je izrisala potreba po kategoriziranju mitske krajine znotraj nesnovne dediščine. Sintetični značaj mitske krajine ob tem kliče po vsaj treh temeljnih upravljavskih nalogah: upravljanju arheoloških najdišč, ustreznem ohranjanju in 
predstavljanju mitskega izročila kot pripovednega izročila ter ohranjanju krajine kot naravne vrednote. Orišemo lahko štiri ključne izzive.

Prvi izziv zadeva interpretacijo. Ker je Mitski park hkrati koncipiran kot sredstvo predstavljanja te dediščine, a tudi kot orodje trajnostnega razvoja kraja skozi turizem, je primarna naloga upravljanja ustrezno izvajanje interpretacije. To je preprečevanje negativnih učinkov, banalizacije in poblagovljenja. Slednje se lahko doseže na več načinov: (a) z upoštevanjem smernic za interpretacijo mitske krajine, ki so bile oblikovane s strani stroke, a na osnovi stikov s skupnostjo (Hrobat Virloget 2021); (b) z rednimi izobraževalnimi in osvežitvenimi tečaji za vodnike in turistične operaterje, ki bi jih bilo potrebno predvideti; (c) z rednim stikom med lokalno skupnostjo, ki bo park upravljala, in zunanjim svetovalnim organom, ki bi ga bilo potrebno oblikovati in ki bi vključeval tudi dediščinsko stroko.

Drugi izziv zadeva samo pripovedno izročilo, katerega ohranjanje je bistveno za mitsko krajino. Skozi interpretacijske dejavnosti za zunanje obiskovalce se bo slednje ohranjalo izven svojega izvornega konteksta, kot folklorizem, za potrebe turistične promocije. A hkrati je ravno priprava vodnikov za to interpretacijsko dejavnost pokazala, da v Rodiku še obstajajo osebe, ki so rodiško pripovedno izročilo prejele na tradicionalen način, tj. od starejših članov svoje družine in skupnosti, ter ga danes v svojem družinskem krogu predajajo dalje. S tega vidika bi med upravljavske naloge umestili tudi spodbujanje nadaljnjih klasičnih etnoloških raziskav med sedanjo lokalno skupnostjo (v Rodiku in v krogu odseljenih Rodičanov, ki se redno vračajo) o njenem odnosu do pripovednega izročila. Pričakovati je, da bodo številni obiskovalci lokalnega izvora na lastno pobudo delili svoje vedenje o mitskem izročilu - kar bi bilo smiselno spodbujati, predvsem pa ustrezno beležiti v Centru za obiskovalce. Obstoj Mitskega parka, in specifično umeščenost centra za obiskovalce v vaški dom, ob tem ponuja priložnost, da se v upravljanje parka vključi tudi organizacija dogodkov za lokalno skupnost samo - npr. pripovedovalski, "pravljičarski« večeri, na katerih bi nosilci (nosilke) ustnega izročila predajali tudi številne druge zgodbe, ki niso vključene $\mathrm{v}$ izjemno selekcioniranih dvanajstih točkah parka. Za potrebe dokumentacije bi bilo ta pričevanja potrebno ustrezno beležiti in popisati. Tovrstni dogodki pa bi predstavljali nov kontekst, kjer bi nosilci izročila le-to lahko predajali mlajšim generacijam. Pomemben del upravljanja bo tako predstavljal tudi ustrezno oblikovan načrt komunikacije, ne samo z zunanjimi deležniki, temveč enakovredno tudi s člani lokalne skupnosti.

Tretji upravljavski izziv pa predstavlja samo ohranjanje krajine kot na- 
ravne vrednote, predvsem izvajanje vseh dejavnosti, ki bodo preprečevale njeno uničevanje. $V$ ta sklop sodijo uravnoteženo in razpršeno usmerjanje obiska v izogib pritisku na posamezne lokacije, vzpostavitev ustrezne signalizacije in varnostnih opozoril (posebej v okolici jam), ureditev in vzdrževanje poti (v izogib uničevanju in onesnaževanju izven poti). Pomembno vlogo bosta $v$ tem segmentu odigrala tudi reden monitoring in dokumentiranje stanja, za katera je potrebno določiti usposobljeno osebo. Tovrstni stalni nadzor bo v prvem obdobju upravljanja pokazal, ali bi bilo smotrno razmisliti o bodisi razširitvi normativnega varstva naravnih vrednot kot krajine ali ovrednotenju kot »območje krajinske prepoznavnosti«.

Ob izzivih, ki izhajajo iz osnovnega pomena mitske krajine, pa samostojen sklop predstavlja čezmejni značaj parka. Analiza je pokazala, da sta dve lokaciji zgolj relativno primerljivi: v Rodiku smo priča kompleksnim nalogam ohranjanja mitske krajine, ki jo sestavljajo številne lokacije in z njimi povezano pripovedno izročilo, v Mošćenički Dragi pa nesnovno dimenzijo mitske krajine tvorijo toponimi. Naloge upravljanja se bodo $v$ teh segmentih razločevale; skupne naloge pa bodo zadevale predvsem tiste elemente, ki so bili vzpostavljeni sinhrono skozi projekt Interreg (načela interpretacije, celostna grafična podoba, čezmejni turistični paket). Uspešnost čezmejne zasnove parka bodo pokazali sledeči kazalniki: najpomembnejši kazalnik bo število obiskovalcev, ki obišče eno lokacijo zaradi druge oz. načrtovano obišče obe lokaciji; drugi kazalnik bo izvedba morebitnih skupnih ali povezanih dogodkov; tretji kazalnik bo število udeležencev nadaljnjih skupnih izobraževanj za vodenje in delo v parku.

Strnemo lahko, da vzpostavitev Mitskega parka predstavlja pomembno študijo primera za razvoj upravljavskih načel in praks. Mitski park namreč načenja pomembno upravljavsko vprašanje: kako enakovredno upravljati hkrati snovno in nesnovno dediščino. Drobec odgovora ponujata tako izkušnja vzpostavitve Mitskega parka v Rodiku kot skupni imenovalec mednarodnih strokovnih načel - osnove trajnostnega ohranjanja dediščine so aktivna vloga lokalne skupnosti ter jasna strokovna izhodišča.

\section{Literatura}

Benjamin, W. 2008. The Work of Art in the Age of Its Technological Reproducibility, and the Writings on Media. Cambridge, MA: The Belknap Press of Harvard University Press.

Bevk, T., J. Hudoklin in A. Mlakar, ur. 2020. Krajinska politika Slovenije. Ljubljana: Društvo krajinskih arhitektov Slovenije.

Cecchi, R., in P. Gasparoli. 2010. Prevenzione e manutenzione per i beni culturali 
edificati: procedimenti scientifici per lo sviluppo di attività ispettive. Firence: Alinea Editrice.

Chitty, J., ur. 2017. "Introduction: Engaging Conservation - Practising Heritage Conservation in Communities."V Heritage, Conservation and Communities: Engagement, Participation and Capacity Building, ur. G. Chitty, 1-16. London: Routledge.

Clark, K. 2014. »Values-Based Heritage Management in the U K. « APT Bulletin: Journal of Preservation Technology 45 (2-3): 65-71.

Doehne, E., in C. A. Price. 2010. Stone Conservation: An Overview of Current Research. Los Angeles: Getty Conservation Institute.

Dolenec, S., in I. Porekar Kacafura. 2013. »Naravni kamen. "Priročnik: muzejska konzervatorska in restavratorska dejavnost 1 (3.3): 1-19.

Draženović, M., in A. Smrekar. 2020. Priročnik za interpretacijo dediščine. Ljubljana: Založba Z RC.

Dumbović Bilušić, B. 2015. Krajolik kao kulturno nasljeđe: metode prepoznavanja, vrjednovanja i zaštite kulturnih krajolika Hrvatske. Zagreb: Ministarstvo kulture Republike Hrvatske.

Evropska konvencija o krajini. 200o. http://www.svetevrope.si/sl/ dokumenti_in_publikacije/konvencije/176/.

Feilden, B. M., in J. Jokilehto. 1998. Management Guidelines for World Cultural Heritage Sites. 2. izd. Rim: IC C R O M.

Heritage Lottery Fund. 2001. Conservation Management Plan. London: Heritage Lottery Fund.

Hrobat Virloget, K. 2019. "O aktivni in pasivni vlogi stroke ter javnosti pri ustvarjanju nesnovne dediščine: primer mitskega parka in starovercev.« $\mathrm{V}$ Nesnovna dediščina med prakso in registri: 15. vzporednice med slovensko in hrvaško etnologijo, ur. A. Svetel in T. Petrović Leš, 24-41. Ljubljana: Slovensko etnološko društvo; Zagreb: Hrvaško etnološko društvo, 2019.

- 2021. »Mitska krajina: razmisleki in smernice za mitski park. V Mitska krajina: iz različnih perspektiv, ur. K. Hrobat Virloget, 17-55. Koper: Založba Univerze na Primorskem.

Hrobat Virloget, K., in P. Kavrečič. 2015. »Mitska krajina Gropade v okviru ustnega izročila na Krasu in širše. "V Nesnovna krajina Krasa, ur. K. Hrobat Virloget in P. Kavrečič, 69-84. Koper: Založba Univerze na Primorskem.

Hudoklin, J., I. Selak in S. Simič, S. 2005. »Ohranjanje prepoznavnosti slovenskih krajin: zaključno poročilo. «Acer Novo mesto, Novo mesto.

International Council on Monuments and Sites. 2008. ICOMOS-IS C S: Illustrated Glossary on Stone Deterioration Patterns/Glossaire illustré sur les formes d'altération de la pierre. Monuments and Sites 15. Pariz: International Council on Monuments and Sites. 
Inaba, N. 2012. „Cultural Landscapes in Japan: A Century of Concept Development and Management Challenges."V Managing Cultural Landscapes, ur. K. Taylor in J. L. Lennon, 109-126. London: Routledge.

Kerr, J. S. 2013. Conservation Plan: A Guide for the Preparation of Conservation Plans for Places of European Cultural Significance. 7th ed. B. k.: Australia ICOMOS.

Kovačič, G. 2021. »Rodiška mitska krajina: geografski vidik."V Mitska krajina: iz različnih perspektiv, ur. K. Hrobat Virloget, 101-122 Koper: Založba Univerze na Primorskem.

Lah, M. 2018. »Kulturna krajina znotraj sistema varstva kulturne dediščine.« Varstvo spomenikov 50:98-117.

Mellucco Vaccaro, A. 1996. »The Idea of Patina. "V Historical and Philosophical Issues in the Conservation of Cultural Heritage, ur. N. S. Price, M. Kirby Talley Jr in A. Mellucco Vaccaro, 365-371. Los Angeles: The Getty Conservation Institute.

Moser, H. 1962. „Vom Folklorismus in unserer Zeit."Zeitschrift für Volkskunde 58 (2): 177-209.

Nikolić Đerić, T. 2018. Smernice razvoje destinacije Claustra+. Reka: Logoteam.

»Odlok o strategiji prostorskega razvoja Slovenije (od S P RS).« 2004. Uradni list Republike Slovenije, št. 76. https://www.uradni-list.si/1/objava.jsp ?sop=2004-01-3397

Palumbo, G. 2000. "Threats and Challneges to the Archaeological Heritage in the Mediterranean."V Management Planning for Archaeological Sites, ur. J. M. Teutonico in G. Palumbo, 3-12. Los Angeles: The Getty Conservation Institute.

Peršolja, M. 200o. Rodiške pravce in zgodbe. Ljubljana: Mladika.

Philippot, P. 1996. "The Idea of Patina and the Cleaning of Paintings«. V Historical and Philosophical Issues in the Conservation of Cultural Heritage, ur. N. S. Price, M. Kirby Talley Jr in A. Mellucco Vaccaro, 372-376. Los Angeles: The Getty Conservation Institute.

Pirkovič, J. 2017. "Koncept kulturne krajine in vloga muzejev pri njenem varstvu.«V Muzeji, dediščina in kulturna krajina: 1. mednarodni kongres slovenskih muzealcev, ur. F. Bonin, 27-40. Radovljica: Slovensko muzejsko društvo; Ljubljana: Skupnost muzejev Slovenije; Celje: I C O M Slovenija.

- 2018. »Uvod v sistematiko arheološke dediščine."Varstvo spomenikov 50:69-84.

Plestenjak, A., in M. Stokin. 2016. „Smernice upravljanja utrdbene dediščine na prostoru slovenske Istre."Varstvo spomenikov 49:7-14.

Plestenjak, A., M. Stokin in K. Zanier. 2014. »Teoretska izhodišča za izdelavo načrta upravljanja kulturnih spomenikov.«Varstvo spomenikov 4748:162-173. 
Poljak Istenič, S. 2008. „Šege in navade kot folklorizem.« Traditiones 37 (2): 61-110.

"Pravilnik o seznamih zvrsti dediščine in varstvenih usmeritvah." 2010. Uradni list Republike Slovenije, št. 102. https://www.uradni-list.si/1/ objava.jsp?sop=2010-01-5232

Price, N. S., M. Kirby Talley Jr in A. Mellucco Vaccaro. 1996. Historical and Philosophical Issues in the Conservation of Cultural Heritage. Los Angeles: The Getty Conservation Institute.

Proschan, F. 2008. „Basic Challenges of Sustaining Intangible Heritage.« V Safeguarding Intangible Heritage and Sustainable Cultural Tourism: Opportunities and Challenges, ur. C. Haddad, 21-26. Bangkok: U N E S CO Bangkok.

Pukl, A. 2012. "Nosilci in register žive kulturne dediščine. "V Priročnik o nesnovni kulturni dediščini, ur. A. Jerin, A. Pukl in N. Židov, 21-26. Ljubljana: Slovenski etnografski muzej.

Rössler, M. 2014. »World Heritage Cultural Landscapes: 1992-2012«. V Conserving Cultural Landscapes: Challenges and New Directions, ur. K. Taylor, A. St Clair in N. J. Mitchell, 29-46. London: Routledge.

Smith, L. 2006. Uses of Heritage. London: Routledge.

Spanžel, Š. 2012. »Konvencija o varovanju nesnovne kulturne dediščine.«V Priročnik o nesnovni kulturni dediščini, ur. A. Jerin, A. Pukl in N. Židov, 9-14. Ljubljana: Slovenski etnografski muzej.

Stanonik, M. 2001. Teoretični oris slovstvene folklore. Ljubljana: Založba Z RC. Štefan, A. 1999. »Folklorno pripovedovanje kot prepletanje izročila in osebne ustvarjalnosti.« Magistrska naloga, Univerza v Ljubljani.

Taylor, K., A. St Clair in N. J. Mitchell. 2014. "Introduction: Cultural Landscapes: Twenty-First Century Conservation Opportunities and Challenges."V Conserving Cultural Landscapes: Challenges and New Directions, ur. K. Taylor, A. St Clair in N. J. Mitchell, 1-28. London: Routledge.

Teutonico, J. M., in F. Matero. 2003. Managing Change: Sustainable Approaches to the Conservation of the Built Environment. Los Angeles: Getty Conservation Institute.

U N E S C O. 2010. "Convention Concerning the Protection of the World Cultural and Natural Heritage World Heritage.« https://whc.unesco.org/ archive/2010/whc10-34Com-9Be.pdf

- 2019. »Operational Guidelines for the Implementation of the World Heritage Convention. «https://whc.unesco.org/document/178167

—. B. l.a. »Fandango's Living Museum.«https://ich.unesco.org/en/BSP/ fandango-s-living-museum-00502

- B.l.b. »Land of Legends." https://ich.unesco.org/en/BSP/land-of -legends-programme-for-promoting-and-revitalizing-the-art-of -storytelling-in-kronoberg-region-01392 
- B. l.c. »Safeguarding of the Art of Akyns, Kyrgyz Epic Tellers. «https: //ich.unesco.org/en/projects/safeguarding-of-the-art-of-the-akyns -kyrgyz-epic-tellers-ooo21

Wijesuriya, G., J. Thompson in C. Young. 2013. Managing World Cultural Heritage. Pariz: U N E S CO.

Willems, J. H. W. 2010. "Laws, Language, and Learning: Managing Archaeological Heritage Resources in Europe."V Cultural Heritage Management: A Global Perspective, ur. P. Mauch Messenger in G. S. Smith. 212-229. Gainesville, F L: University of Florida.

"Zakon o ohranjanju narave (ZON-U P B 2).« 2004. Uradni list Republike Slovenije, št. 96. https://www.uradni-list.si/1/objava.jsp?sop=2004-01 -4233 .

"Zakon o varstvu kulturne dediščine (z V K D-1).« 2008. Uradni list Republike Slovenije, št. 16. https://www.uradni-list.si/1/objava.jsp?sop=2008-01 $-0485$

»Zakon o varstvu podzemnih jam (z P V J)." 2004. Uradni list Republike Slovenije, št. 2. https://www.uradni-list.si/1/objava.jsp?sop=2004-01 $-0067$

Žele, B. 2003. "Slovensko ljudsko izročilo in moderno poustvarjanje.« Diplomsko delo, Univerza v Ljubljani.

Židov, N. 2014. "Nesnovna kulturna dediščina Slovenije: dileme pri varovanju v luči Unescove konvencije."V Interpretacije dediščine, ur. T. Dolžan Eržen, I. Slavec Gradišnik in N. Valentinčič Furlan, 150-161. Ljubljana: Slovensko etnološko društvo.

\section{Poskus orisa izzivov v upravljanju Mitskega parka v Rodiku}

Cilj poglavja je opisati nekaj ključnih izzivov pri upravljanju Mitskega parka $\mathrm{v}$ Rodiku in slednjega ponuditi kot primer za določanje upravljavskih nalog v primerih »asociativne kulturne krajine« v evropskem okviru. V prvem delu sta predstavljena sodobna definicija upravljanja dediščine kot »upravljanje ustvarjalne kontinuitete in družbeno kohezivnih dediščinskih praks" (Chitty 2017) in njen na vrednotenju osnovan pristop, ki temelji na sodelovanju s skupnostjo. Primer tega bo sistem upravljanja v Rodiku: uradno ga bo koordiniral režijski obrat občine, v katerem bodo aktivni lokalni prebivalci. V osrednjem delu prispevka analiziramo »mitsko krajino« skozi elemente - ki jih sestavljajo registrirana dediščina (predvsem arheološka najdišča), umetniška dela, ustvarjena za park, naravne vrednote in kulturna krajina, nesnovna dediščina - ter izpostavljamo vprašanje ranljivosti. Štiri registrirana arheološka najdišča so del parka, dva izmed njih imata status spomenika lokalnega pomena, za katere je po zakonu predviden načrt upravljanja; glavni prepoznani nalogi sta spremljanje stanja in preventivno vzdrževanje. Vzdrževanje bo osrednja naloga tudi za umetniška dela v parku. $\mathrm{Na}$ 
območju parka je prisotnih tudi več zavarovanih naravnih območij in vrednot (jam), katerih varstveni režimi zadevajo zlasti dostopnost. Posledično se zastavlja vprašanje zaščite območja parka kot kulturne krajine in se pojavlja osrednji problem opredelitve: $v$ rodiškem primeru imamo opravka s kategorijo asociativne krajine, orodje varstva in upravljanja pa ponuja prostorsko načrtovanje. Nenazadnje, nesnovna dimenzija krajine, sestavljena iz pripovednega izročila "pravc«, zahteva posebne naloge upravljanja: identifikacijo obstoječih tradicionalnih pripovedovalcev zgodb v skupnosti (za omogočanje in spodbujanje prenosa) ter predvsem ustrezno izobraževanje sodobnih interpretatorjev dediščine za obiskovalce (v izogib banalizaciji). Zadnji ključni vidik je čezmejni značaj parka, saj je ta sestavljen iz dveh fizično ločenih lokacij v dveh državah. Opozorili smo na analogije z upravljanjem serijskih (U NESCO) lokacij in poudarili potrebo po skupnem interpretacijskem pristopu, obenem s skupnimi načrtovanjem, promocijo in spremljanjem obiska.

\section{An Attempt to Outline the Challenges in the Management of the Myth Park in Rodik}

The chapter aims to outline some key challenges in the management of the Mythical Park in Rodik and propose it as platform for defining management task for cases of 'associative cultural landscape' in the European context. The first part introduces the contemporary definition of conservation management as 'the management of creative continuity and socially cohesive heritage practice' (Chitty 2017) and its values-based and community-led approach. The management system in Rodik will be an example of it: coordinated officially by an 'public utility unit' (režijski obrat) of the Municipality, in which local inhabitants will be active. In the core part the 'mythical landscape' is analysed through the elements that compose it (listed heritage - archaeological sites mainly -, artworks created for the park, natural sites and cultural landscape, intangible heritage) along with vulnerability issues. Four registered archaeological sites are part of the park, two of them listed as monuments of local importance, for which a management plan is required by law, the main task identified is monitoring and preventive maintenance. Maintenance will be a central task also for the artworks in the park. Several protected natural sites (caves) are also present, their protection regimes tackle especially accessibility to the caves. Hence, the issue of protecting the park area as cultural landscape is raised and the central problem of definition arises: the Rodik's one is an example of associative landscape but can only be protected with spatial planning tools. Lastly, the intangible dimension of the landscape, composed of the oral tradition of tales, requires specific management tasks: identification of the existing traditional storytellers in the community (to enable and stimulation transmission); adequate training of contemporary storytellers-interpreters for 
visitors (to avoid banalisation). A last key aspect is the cross-border character of the park since it is composed of two disconnected sites in bordering countries. So, analogies with management of serial (U N E SCO) sites are pinpointed, and the need for a joint interpretation approach is stressed, along with joint planning, promotion and monitoring of visits.

\section{Pokušaj ocrtavanja izazova u upravljanju Mitskog parka u Rodiku}

Cilj ovog poglavlja je opisati neke ključne izazove u upravljanju Mitskim parkom u Rodiku i isto ponuditi kao primjer za utvrđivanje zadataka upravljanja parkom u slučajevima »asocijativnog kulturnog krajolika« u europskom kontekstu. Prvi dio predstavlja suvremenu definiciju upravljanja baštinom kao »upravljanje kreativnim kontinuitetom i društveno kohezivnim praksama baštine" (Chitty 2017) i pristup zasnovan na evaluaciji i na suradnji sa zajednicom. Primjer za to bit će sustav upravljanja parkom u Rodiku: službeno će ga koordinirati općinsko javno tijelo u kojem će se aktivirati lokalno stanovništvo. U glavnom dijelu rada analiziramo "mitski krajolik" kroz elemente od kojih je sastavljen (registrirana baština, prije svega arheološka nalazišta, umjetnička djela kreirana za park, prirodne vrijednosti i kulturni krajolik, nematerijalna baština) i postavljamo pitanje njegove ranjivosti. Četiri registrirana arheološka nalazišta dio su parka, od kojih dva imaju status spomenika od lokalnog značenja, za što je zakonom predviđen plan upravljanja; glavni identificirani zadaci su praćenje i preventivno održavanje. Održavanje će biti glavni zadatak koji će se odnositi i na umjetnička djela u parku. Na području parka postoji i nekoliko zaštićenih prirodnih područja i vrijednosti (špilja) čiji se režimi zaštite posebno odnose na njihovu pristupačnost. Kao rezultat toga, postavlja se pitanje zaštite područja parka kao kulturnog krajolika i nastaje glavni problem definicije: u slučaju Rodika bavimo se kategorijom asocijativnog krajolika, dok alat za zaštitu i upravljanje nudi prostorno planiranje. Na kraju, ali ne najmanje važno, nematerijalna dimenzija krajolika koja se sastoji od narativne tradicije "priča» zahtijeva posebne zadatke upravljanja: identificiranje postojećih tradicionalnih pripovjedača unutar zajednice (kako bi se omogućio i potaknuo prijenos) i prije svega odgovarajuću edukaciju suvremenih tumača baštine za posjetitelje (kako bi se izbjegla banalizacija). Posljednji ključni aspekt je prekogranični karakter parka jer se sastoji od dvije fizički odvojene lokacije u dvije države. Skrenuli smo pozornost na analogije upravljanja serijskim (U N E S COovim) nalazištima i naglasili potrebu za zajedničkim interpretativnim pristupom koji će biti objedinjen sa zajedničkim planiranjem, promidžbom i praćenjem posjeta. 